\title{
ANTIBACTERIAL COMPOUND BASED ON SILICONE RUBBER AND ZnO AND TiO, NANOPARTICLES FOR THE FOOD AND PHARMACEUTIC INDUSTRIES. PART II - BIOLOGICAL AND MORPHOLOGICAL CHARACTERIZATION
}

\author{
Mihaela NIJUICĂ (VÎLSAN) ${ }^{1 *}$, Maria SÖNMEZ ${ }^{1}$, Mihai GEORGESCU ${ }^{1}$, Maria Daniela STELESCU ${ }^{1}$, \\ Laurenţia ALEXANDRESCU ${ }^{1}$, Dana GURĂU ${ }^{1}$, Carmen CURUTIU ${ }^{2,3}$, Lia Maria DIJU ${ }^{2,3}$ \\ ${ }^{1}$ INCDTP - Division Leather and Footwear Research Institute, 93 Ion Minulescu St., sector 3, Bucharest, \\ mihaela.nituica@icpi.ro,mihaelavilsan@yahoo.com \\ ${ }^{2}$ University of Bucharest, Faculty of Biology, 1-3 Portocalelor St., 6th district, 060101, Bucharest, Romania
}

${ }^{3}$ Research Institute of University of Bucharest, 36-46 M. Kogalniceanu St., 5th district, 050107, Bucharest, Romania

Received: 26.05 .2020

Accepted: 25.07.2020

https://doi.org/10.24264/Ifj.20.3.3

ANTIBACTERIAL COMPOUND BASED ON SILICONE RUBBER AND ZnO AND TiO 2 NANOPARTICLES FOR THE FOOD AND PHARMACEUTIC INDUSTRIES. PART II - BIOLOGICAL AND MORPHOLOGICAL CHARACTERIZATION

ABSTRACT. The aim of this paper is the biological and morphological characterization of an antibacterial compound based on silicone rubber (Elastosil R701/70-OH), reinforced with $\mathrm{ZnO}$ and $\mathrm{TiO}_{2}$ nanopowders (with antibacterial, antifungal and antimicrobial properties), charged (chalk), crosslinked with peroxide (dicumyl peroxide - powder $40 \%$ with calcium carbonate and silica, specific to the food, pharmaceutical, but also medical field). $\mathrm{ZnO}$ and $\mathrm{TiO}_{2}$ nanopowders, by their homogeneous dispersion in the mass of the compound, have a determined role on its antibacterial and antimicrobial sterilization properties. The mixture of antibacterial compound based on silicone rubber was made on a laboratory roller, provided with cooling, in the form of a sheet (maximum thickness $5 \mathrm{~mm}$ ), in strict compliance with the technological recipe and the established mode of operation. Subsequently, the mixture is processed into forming molds at predetermined parameters by determining the vulcanization time using the Monsanto rheometer (to determine the optimum temperature and vulcanization times), but also the biological and morphological characterization, according to current standards in specific food and pharmaceutical environments. KEY WORDS: silicone elastomer, biological characterization, nanopowders, antibacterial

\section{COMPOUND ANTIBACTERIAN PE BAZĂ DE ELASTOMER SILICONIC ȘI NANOPARTICULE DE ZnO ȘI TiO PENTRU DOMENIUL ALIMENTAR ȘI FARMACEUTIC. PARTEA II - CARACTERIZARE BIOLOGICĂ ȘI MORFOLOGICĂ}

REZUMAT. Scopul acestei lucrări este caracterizarea din punct de vedere biologic și morfologic a unui compound antibacterian pe bază de cauciuc siliconic (Elastosil R701/70-OH), ranforsat cu nanopulberi de $\mathrm{ZnO}_{\text {și TiO }}$ (cu proprietăți antibacteriene, antifungice și antimicrobiene), șarjat (cretă), reticulat cu peroxid (peroxid de dicumil - pulbere $40 \%$ cu carbonat de calciu și silice, specific domeniului alimentar, farmaceutic, dar și medical). Nanopulberile de $\mathrm{ZnO}$ și $\mathrm{TiO}_{2}$ prin dispersia lor omogenă în masa compoundului au rol determinant asupra proprietăților de sterilizare antibacteriană și antimicrobiană ale acestuia. Amestecul de compound antibacterian pe bază de cauciuc siliconic s-a realizat pe un valț de laborator, prevăzut cu răcire, sub forma unei foi (grosime de maxim $5 \mathrm{~mm}$ ), cu respectarea strictă a rețetei tehnologice și a modului de operare stabilit. Ulterior amestecul este prelucrat in matrițe de formare la parametrii prestabiliți prin determinarea timpului de vulcanizare cu ajutorul reometrului Monsanto (pentru stabilirea temperaturii și timpilor de vulcanizare optimi), dar și a caracterizării biologice și morfologice, conform standardelor în vigoare în medii specifice domeniului alimentar, dar și farmaceutic.

CUVINTE CHEIE: elastomer siliconic, caracterizare biologică, nanopulberi, antibacterian

COMPOSÉ ANTIBACTÉRIEN À BASE DE CAOUTCHOUC DE SILICONE ET DE NANOPARTICULES DE ZnO ET TiO, POUR LES INDUSTRIES ALIMENTAIRE ET PHARMACEUTIQUE. PARTIE II - CARACTÉRISATION BIOLOGIQUE ET MORPHOLOGIQUE

RÉSUMÉ. L'objectif de cet article est la caractérisation biologique et morphologique d'un composé antibactérien à base de caoutchouc silicone (Elastosil R701/70-OH), renforcé de nanopoudres de $\mathrm{ZnO}$ et $\mathrm{TiO}_{2}$ (aux propriétés antibactériennes, antifongiques et antimicrobiennes), chargé (craie), réticulé au peroxyde (peroxyde de dicumyle - poudre à $40 \%$ avec carbonate de calcium et silice, spécifique aux domaines alimentaire, pharmaceutique et médical). Les nanopoudres de $\mathrm{ZnO}$ et $\mathrm{TiO}_{2}$ par leur dispersion homogène dans la masse du composé, ont un rôle déterminant sur les propriétés de stérilisation antibactériennes et antimicrobiennes. Le mélange de composé antibactérien à base de caoutchouc silicone a été réalisé sur un rouleau de laboratoire, avec refroidissement, sous forme de feuille (épaisseur de maximum 5 mm), en respectant strictement la recette technologique et le mode de fonctionnement établi. Par la suite, le mélange est transformé en moules de formage à des paramètres prédéterminés en déterminant le temps de vulcanisation à l'aide du rhéomètre Monsanto (pour déterminer la température optimale et les temps de vulcanisation), mais aussi la caractérisation biologique et morphologique, selon les normes actuelles dans des environnements alimentaires et pharmaceutiques.

MOTS-CLÉS : élastomère de silicone, caractérisation biologique, nanopoudres, antibactérien

\footnotetext{
* Correspondence to: Mihaela NIȚUICĂ (VÎLSAN), INCDTP - Division Leather and Footwear Research Institute, 93 lon Minulescu St., sector 3, Bucharest,mihaela.nituica@icpi.ro,mihaelavilsan@yahoo.com
} 


\section{INTRODUCTION}

Silicone elastomers - silicone rubber is generally processed at high temperatures up to a maximum of $+320^{\circ} \mathrm{C}$ (the processing temperature range is between $-100^{\circ} \mathrm{C}$ to above $+320^{\circ} \mathrm{C}$ ), is indoor, non-toxic, has resistance to ozone, resistance to low temperatures and environments $\left(-100^{\circ} \mathrm{C}\right)$ while maintaining its properties, also has excellent electrical insulation performance. Silicone rubber is preferred in food, pharmaceutical and medical fields due to these properties and its ease of processing and modeling, but also due to its sterilization properties, as a result of processing at high temperatures up to $+320^{\circ} \mathrm{C}[1-7]$.

The development of new materials coated with various nanoparticles in order to inhibit bacterial adhesion to the substrate, thus eliminating their chance to trigger an infectious process has been intensively studied recently [8-10]. The nanoparticles normally have a high surface/volume ratio, ensuring a much more effective antibacterial and antifungal activity. So, their dispersion in elastomeric compounds have a decisive role in influencing the antimicrobial and antibacterial sterilization properties [11]. Due to their antimicrobial, antibacterial and antifungal activity, $\mathrm{ZnO}$ and $\mathrm{TiO}_{2}$ nanoparticles are used for countless applications in everyday life, such as medical devices, dental implants, the textile industry, plastics, antibacterial coatings, building materials, etc. [12-16].

The aim of the paper was to characterize an antibacterial compound biologically, in specific environments (for the pharmaceutical and food industries: Staphylococcus aureus ATCC 25923; Escherichia coli ATCC 25992 and Candida albicans ATCC 10231) [17] and morphologically. The tested antibacterial compound is based on silicone elastomer (rubber Elastosil R701/70-OH - the majoritarian material), charged with chalk, stearin as plasticizer, crosslinked with dicumyl peroxide on silica support and reinforced with zinc oxide and titanium dioxide nanopowders in different percentages, obtained by the technique of mixing on an electric roller. The test specimens and the related characterizations were obtained in the electric press at vulcanization times and temperatures established from the rheological analysis [18-22].

\section{EXPERIMENTAL}

\section{Materials}

Materials used to obtained the antibacterial compound based on siliconic elastomer, reinforced with nanopowders are: Elastosil R701/70-OH (silicon rubber: polydimethylsiloxane with vinyl groups, dynamic viscosity over $9.000 .000 \mathrm{mPa} * \mathrm{~s}$, in the form of paste, density - $1.32 \mathrm{~g} / \mathrm{cm}^{2}$, colour - opaque); stearin (white flakes, moisture $-0.5 \%$ max, ash - $0.025 \%$ max); ZnO (microparticles: white powder, precipitate 93-95\%, density - $5.5 \mathrm{~g} /$ $\mathrm{cm}$, specific surface $-45-55 \mathrm{~m}^{2} / \mathrm{g}$ ); ZnO (zinc oxide nanoparticles- white powder, size particles $20 \mathrm{~nm}$, molecular mass $-98.87 \mathrm{~g} / \mathrm{mol}$, specific surface area $-23 \mathrm{~m}^{2} / \mathrm{g}$, density $-4.26 \mathrm{~g} / \mathrm{ml}$, and concentration - 99,5\%); $\mathrm{TiO}_{2}$ (titanium dioxide nanoparticles: white nanopowder, particle size $21 \mathrm{~nm}$, molecular mass $-79.87 \mathrm{~g} / \mathrm{mol}$, specific surface area $-23 \mathrm{~m}^{2} / \mathrm{g}$, density $-4.26 \mathrm{~g} / \mathrm{ml}$, assay $\geq 99.5 \%$ trace metals basis); chalk $\left(\mathrm{CaCO}_{3}\right.$ precipitate - white powder, molecular weight 100.09); PD (dicumyl peroxide, powder $40 \%$ with calcium carbonate and silica - Perkadox 14-40B $\left(1.65 \mathrm{~g} / \mathrm{cm}^{3}\right.$ density, $3.8 \%$ active oxygen content, pH 7, assay: $39.0-41.0 \%)$ ).

For the biological characterization were used the following materials: Staphylococcus aureus ATCC 25923; Escherichia coli ATCC 25992; Candida albicans ATCC 10231. The abovementioned strains come from American Type Culture Collection (ATCC, US).

\section{Methods}

\section{Preparation of Antibacterial Compound}

The antibacterial compound mixtures were made by the mixing on a laboratory roller provided with cooling, with strict observance of the technological recipe, Table 1 , and the established mixing times (Figure 1) [21]. The silicone rubber - Elastosil R701/70-OH (elastomer) was plasticized between the rolls for approximately 2.5-3 minutes, then the stearin is added and the mixing is continued for 2 minutes. The $\mathrm{ZnO}$ microparticles were blended for a maximum of 2 minutes until the mixture became homogeneous, and the $\mathrm{ZnO}$ and $\mathrm{TiO}_{2}$ nanopowders were added to the mass of the 

INDUSTRIES. PART II - BIOLOGICAL AND MORPHOLOGICAL CHARACTERIZATION

compound continuing the mixing for 3 minutes. Then mixing was continued for 3 minutes, then chalk was added, and after that the last ingredient was added - PD (dicumyl peroxide), continuing mixing for 3 minutes. The mixture is homogenized on the roll mill for maximum 2 minutes and taken off in the form of a 3-4 $\mathrm{mm}$ thick sheet. After the optimal vulcanization time is established, Figure 1 [21], the specimens are processed in the electric press, then subjected to physical-mechanical, chemical, biological and morpho-structural characterization, according to the standard in force, after their stabilization for $24 \mathrm{~h}$ at room temperature [21].

Table 1: Formulation of antibacterial compounds based on silicone rubber reinforced with $\mathrm{TiO}_{2}$ and ZnO nanoparticles [21]

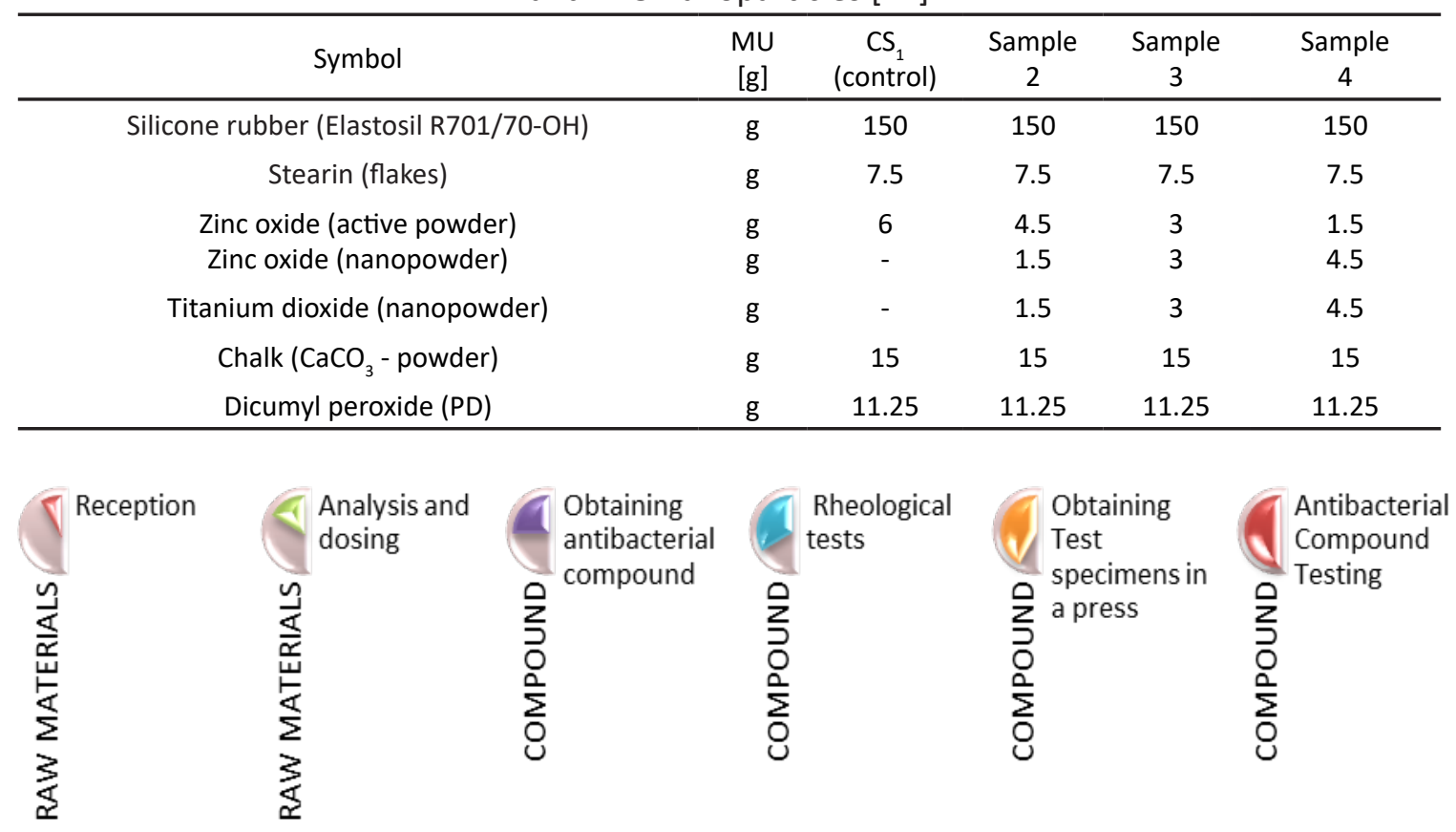

Figure 1. Technological process of obtaining the antibacterial compound reinforced with $\mathrm{ZnO}$ and $\mathrm{TiO}_{2}$ nanopowders [21]

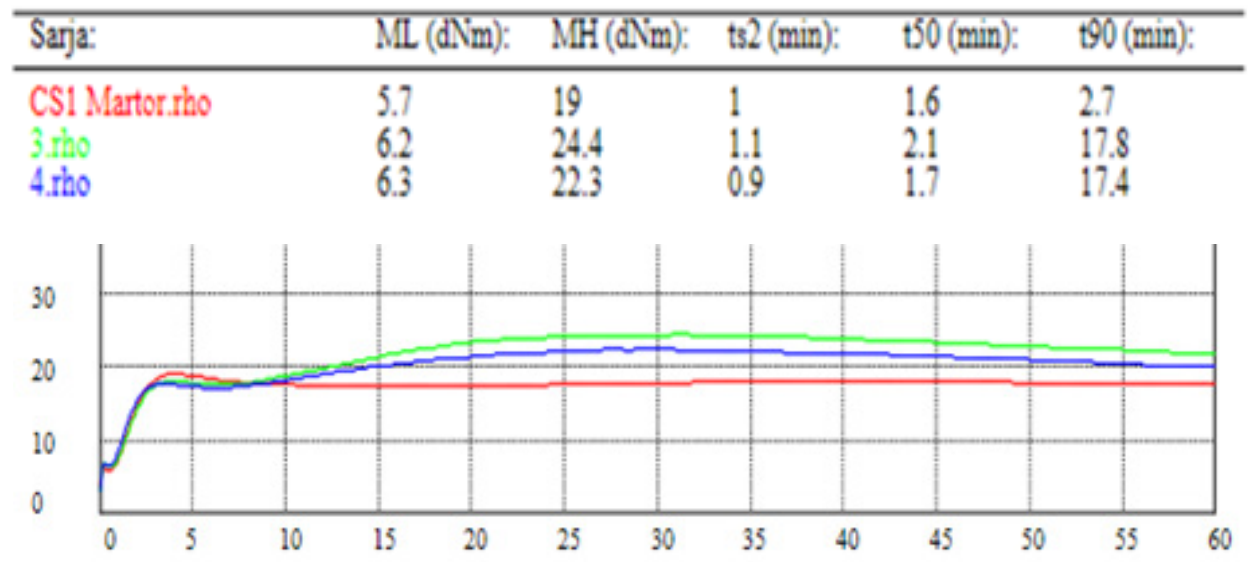

Figure 2. Rheological analysis of sample $\mathrm{CS}_{1}$ (control), sample 3, sample 4, to establish the curing time in the electrical press [21] 


\section{Biological Setup}

To analyze the antimicrobial activity (biological setup), the antibacterial compound specimens based on siliconeelastomer, reinforced with nanopowders with antifungal, antibacterial and antimicrobial properties, $\mathrm{ZnO}$ and $\mathrm{TiO}_{2}$, were tested and characterized according to ASTM standard: E 2149-10. They were tested on the following strains: Staphylococcus aureus ATCC 25923; Escherichia coli ATCC 25992 and Candida albicans ATCC 10231 and preserved on glycerol medium, were seeded on nutrient gelatin agar medium and Sabouraud dextrose agar with chloramphenicol, to obtain $24 \mathrm{~h}$ cultures. All samples were sterilized and placed in six-well plates - Nunc with $200 \mu \mathrm{l}$ microbial suspension (density 0.5 McFarland = $1.5 \times 108 \mathrm{CFU} / \mathrm{mL}$ ) and $2 \mathrm{ml}$ broth for bacteria. For fungi, the microbial suspension had a density of 1 McFarland, i.e. $3 \mathrm{x}$ $108 \mathrm{CFU} / \mathrm{ml}$. Incubation took place at $37^{\circ} \mathrm{C}$ for 24 hours. After the incubation process the colonized materials were washed with sterile distilled water to remove non-adherent microorganisms, then they were introduced into Eppendorf tubes with $1 \mathrm{ml}$ of physiological serum, also sterile (AFS). These were sonicated at maximum power for 15 seconds and then vortexed for 15 seconds at $300 \mathrm{rpm}$. Then, decimal dilutions were made, which were seeded in triplicate of $10 \mu \mathrm{l}$ per nutrient agar medium, namely Sabouraud with chloramphenicol, to calculate the number of colony-forming units/ml - CFU.

\section{Morphological Characterisation}

The antibacterial compounds based on silicone rubber, reinforced with nanopowders with antifungal, antibacterial and antimicrobial properties and crosslinked with dicumyl peroxide, obtained by mixing technique, were morphologically tested by scanning electron microscopy - SEM. Microscopic analyses were performed using an electron microscope at $15 \backslash 20$ $\mathrm{keV}$, in the primary electron beam, on specimens covered with a gold film, to highlight the degree of dispersion of nanopowders, but also changes in the surface of the elastomer. The microscope generates a flow of electrons that bombard the sample, allowing a clear view of the structure of the sample under analysis. The lower surface, the upper surface, but also the transverse one can be visualized.

\section{RESULTS AND DISCUSSIONS}

\section{Biological Characterization of Antibacterial Compounds}

There are different types of nanoparticles (nanopowders) that can be incorporated into the elastomer matrix, depending on their properties and their application. Thus, various studies have been performed for the development and use of new materials mixed with different types of nanopowders to limit bacterial adhesion to the surface, thus eliminating the possibility of triggering an infectious process.

The antibacterial compound based on silicone elastomer, reinforced with $\mathrm{ZnO}$ and $\mathrm{TiO}_{2}$ powders (with antifungal, antibacterial and antimicrobial properties) was tested for $24 \mathrm{~h}$ at $37^{\circ} \mathrm{C}$ on:

$>$ Staphylococcus aureus as a model for Gram positive bacteria,

- Escherichia coli (E. coli) as prototype for Gram negative bacteria,

\section{Candida albicans (C. albicans) as a} representative of fungi.

This type of species is among the most frequently isolated species from infections, with an increased incidence in nosocomial ones. Thus, in this study, the antimicrobial, antibacterial and antifungal activity of the antibacterial compound surfaces mixed with $\mathrm{ZnO}$ and $\mathrm{TiO}_{2}$ nanopowders was tested. 


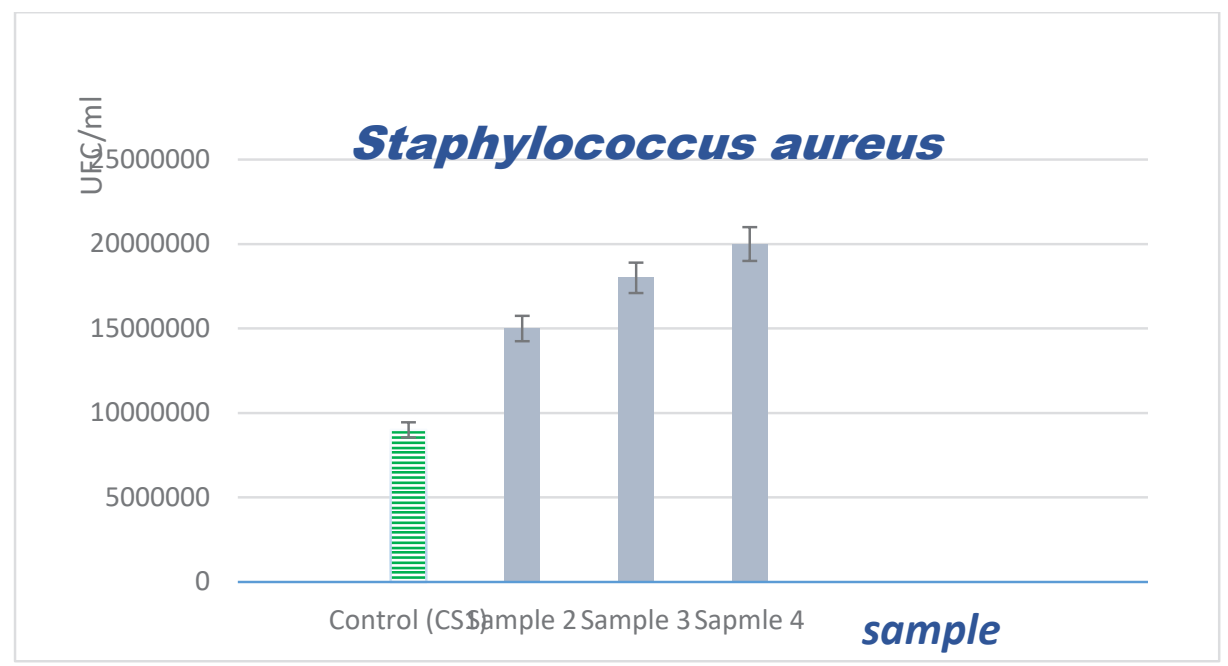

Figure 3. Biological characterization of antibacterial compound samples with $\mathrm{ZnO}$ and $\mathrm{TiO}_{2}$ nanopowders on Staphylococcus aureus ATCC 25923 strains

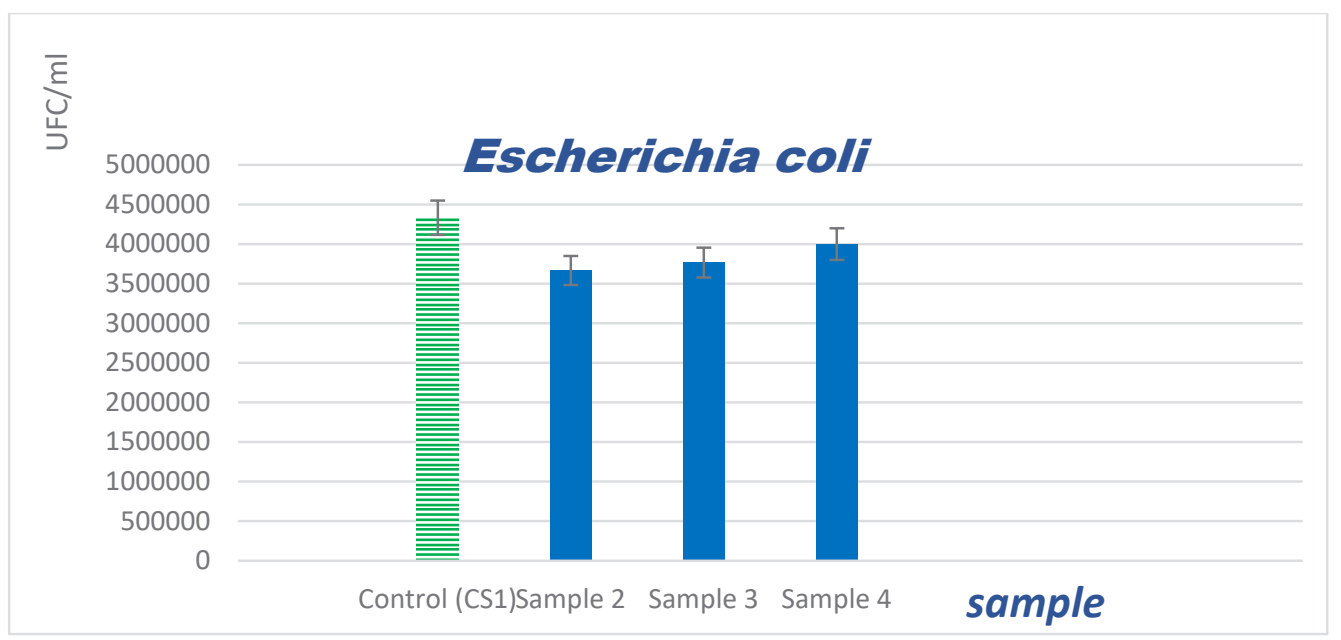

Figure 4. Biological characterization of antibacterial compound samples with $\mathrm{ZnO}$ and $\mathrm{TiO}_{2}$ nanopowders on Escherichia Coli ATCC 25992 strains

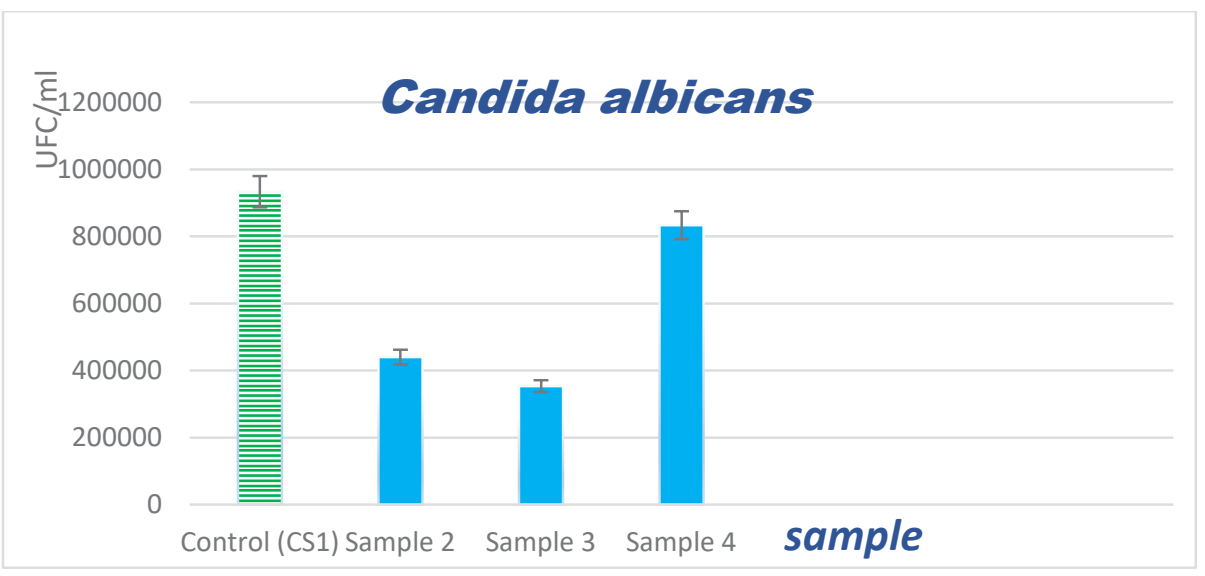

Figure 5. Biological characterization of antibacterial compound samples with $\mathrm{ZnO}$ and $\mathrm{TiO}_{2}$ nanopowders on Candida albicans ATCC 10231 strains 
Tests performed on these types of strains showed that the specimens with zinc oxide and titanium dioxide nanopowders show adhesion capacity compared to the $\mathrm{CS}_{1}$ sample (control sample) depending on the concentration of nanopowders introduced in the antibacterial compound mixture.

The tests performed on fungi, Candida albicans, proved to be very effective in all the tested samples (Sample 2, Sample 3 and Sample 4), sample 3 showing the most effective values against the mentioned fungal species. Also in the case of Gram-negative bacterial strains Escherichia coli, we can see that all samples, especially sample 2 , show effective antimicrobial activity.

The antimicrobial activity tested against Gram-positive bacteria - Staphylococcus aureus, in this case favors bacterial adhesion on the tested samples, the $\mathrm{CFU} / \mathrm{ml}$ values being high compared to the values recorded for the control sample - $\mathrm{CS}_{1}$.

\section{Morphological Characterization of Antibacterial Compounds}

Elastosil R701/70 silicone rubber antibacterial compound specimens (which is the main component) reinforced with $\mathrm{ZnO}$ and $\mathrm{TiO}_{2}$ nanoparticles were analyzed using the Hitachi S2600N electrocopic microscope at 15-20 keV in the primary electron beam, in cross-section, on samples covered with gold film. The SEM images are shown in Figures 6 and 7, where the dispersion of nanoparticles with antimicrobial, antifungal and antibacterial role in the obtained antibacterial compound can be observed.

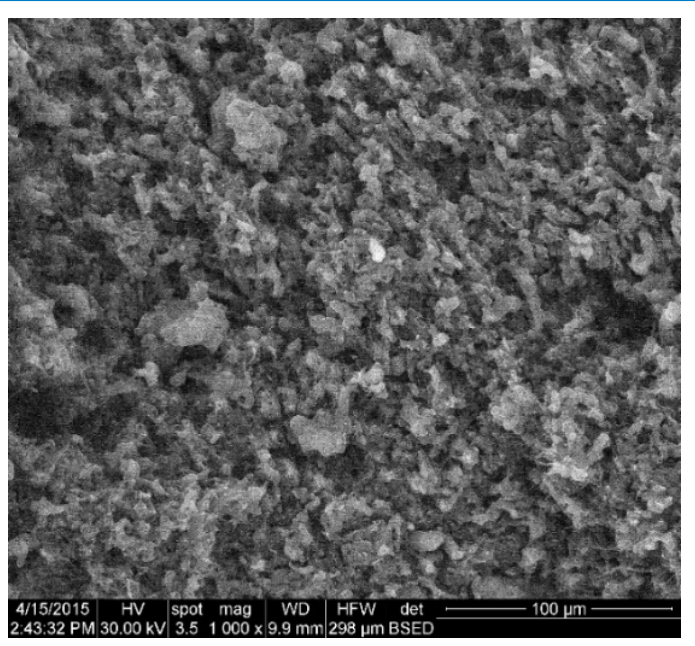

Figure 6. SEM image recorded for sample 2

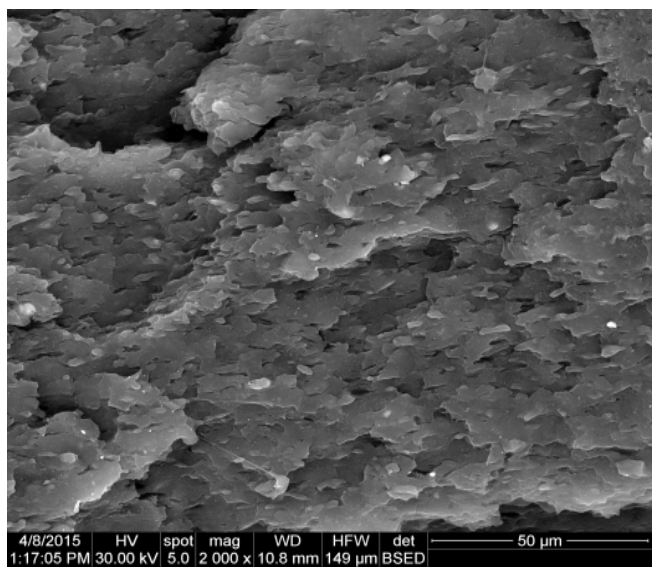

Figure 7. SEM image recorded for sample 3

The images of the samples recorded in cross section show a biphasic morphology, with $\mathrm{ZnO}$ and $\mathrm{TiO}_{2}$ nanopowder particles evenly distributed in the elastomeric matrix (silicone rubber being the major component in which all other components are dispersed), thus leading to an improvement of characteristics of the compound (resistance, elasticity, increased microbial activity, etc.).

There is also a homogeneous dispersion of all components in the mass of the antibacterial compound, thus demonstrating that it was performed at optimal parameters according to the plan.

\section{CONCLUSION}

The paper presents the biological and morphological characterization of antibacterial compounds based on silicone rubber, reinforced with zinc oxide and titanium dioxide 
nanopowders and crosslinked with dicumyl peroxide. The biological characterization was performed on strains specific to the food and pharmaceutical field according to the standards in force, for 24 hours at $37^{\circ} \mathrm{C}$. The three strains used are Staphylococcus aureus ATCC 25923, Escherichia coli ATCC 25992 and Candida albicans ATCC 10231. The standard used for the biological test of the antibacterial compound based on silicone rubber and $\mathrm{ZnO}$ and $\mathrm{TiO}_{2}$ nanopowders was ASTM: E 2149-10 standard.

According to the biological characterization performed, samples 2 and 3 show effective antimicrobial activity against both fungi Candida albicans, and Gram-negative bacteria Escherichia coli.

The morphological characterization showed that the tested specimens were performed according to the vulcanization times and temperatures determined from the rheological analysis (using the Monsanto rheometer) and a homogeneous dispersion of both $\mathrm{ZnO}$ and $\mathrm{TiO}_{2}$ nanopowders and other components used in the mass of the compound.

As a result of the biological and morphological characterization of antibacterial compounds based on sliconic elastomer we can say that they have potential applications in both the pharmaceutical and food fields, especially samples 2 and 3.

\section{Acknowledgements}

This research was financed by ANCSI through PN 16-34 01 10/2016 project: "Antibacterial compound based on silicone rubber and $\mathrm{ZnO}$ and $\mathrm{TiO}_{2}$ nanoparticles processed by vulcanization", Sectoral projects, No. 3PSI/2019, "Research on risks caused by materials coming into contact with food, per groups of materials. Harmonization with European law" and 6PFE/2018 - PERFORM-TEXPEL.

\section{REFERENCES}

1. Dobrinescu, A., New types of elastomers for special purposes, Ministry of Light Industry, Centre for Documentation and Technical Publications, Bucharest, 1971.

2. Mirici, L.E., Thermoplastic Elastomers, Art. Press \& Augusta, Timisoara, 2005.
3. Volintiru, T., Ivan, Gh., Technological bases of processing elastomers, Technical Press, Bucharest, 1974.

4. Stelescu, M.D., Characteristics of silicone rubber blends, Leather and Footwear Journal, 2010, 10, 3, 51-58.

5. Shi, F., Clayman, R., Louie, M.K., Lin, Y.H., Lin, Y.C., Silicone composition and devices incorporating same, US Patent 8,257,827 B1, 4 September 2012.

6. Huang, X., Tian, Z., Zhang, D., Jing, Q., Li, J., The synergetic effect of antimony $\left(\mathrm{Sb}_{2} \mathrm{O}_{3}\right)$ and melanine cyanurate (MCA) on the flameretardant behavior of silicon rubber, Polym Bull, 2020, 75, https://doi.org/10.1007/ s00289-019-03098-y.

7. Hanke, B., Bort, F., Anti-microbial silicone rubber composition and method for making same, US Patent 6,822,034 B2, 23 November 2004.

8. Zeng, L., Zhang, Y., Rao, Z., Liu, Y., Miao, X., Ma, L., Yan, N., Zeng, X., Zhou, L., Zou, Y., Tong, C., Deng, Z., Study on Thermal Aging Characteristics of HTV Silicone Rubber Sheds of Composite Insulators, IOP Conference Series Materials Science and Engineering 782:022076, https://doi. org/10.1088/1757-899X/782/2/022076, April 2020.

9. Zhou, H., Wang, H., Niu, H., Gestos, A., Wang, $X .$, Lin, T., Fluoroalkyl silane modified silicone rubber/nanoparticle composite: a super durable, robust superhydrophobic fabric coating, Adv Mater, 2012, 24, 2, 409-2412, https://doi.org/10.1002/adma.201200184.

10.Chandra, J., Kuhn, D.M., Mukherjee, P.K., Hoyer, L.L., McCormick, T., Ghannoum, M.A., Biofilm Formation by the Fungal Pathogen Candida albicans: Development, Architecture, and Drug Resistance, J Bacteriol, 2001, 183, 18, 5385-5394, PMCID: PMC95423, https:// doi.org/10.1128/JB.183.18.5385-5394.2001.

11.Byeon, Y., Jeon, Y., Kim, M., Research on AC Tracking Resistance of Silicone Rubber/BN Microcomposites, Trans Korean Inst Electr Eng, 2019, 68, 11, 1, 389-1395, https://doi. org/10.5370/KIEE.2019.68.11.1389. 
12.Hwang, S., Ryu, H.J., Kim, Y., So, J.I., Jin, S.H., Baeck, S.H., Shim, S.E., Thermal Stability and Mechanical Properties of Silicone Rubber Composites Filled with Inorganic Fire-proof Fillers and Expandable Materials, Polym Korea, 2018, 42, 3, 354-363, https://doi. org/10.7317/pk.2018.42.3.354.

13.Fallahi, D., Mirzadeh, H., Khorasani, M.T., Physical, mechanical, and biocompatibility evaluation of three different types of silicone rubber, J Appl Polym Sci, 2003, 8, 2522-2529, https://doi.org/10.1002/app.11952.

14. Hron, P., Slechtova, J.,Smetana, K., Dvorankova, B., Lopour, P., Silicone rubber-hydrogel composites as polymeric biomaterials, IX. Composites containing powdery polyacrylamide hydrogel, Biomaterials, 1997, 18, 15, 1069-1073, https://doi.org/10.1016/ S0142-9612(97)00039-2.

15.Otto, M., Staphylococcal Biofilms, Curr Top Microbiol Immunol, 2008, 322, 207-228, https://doi.org/10.1007/978-3-540-754183_10.

16. Mashak, A., In vitro drug release from silicone rubber-polyacrylamide composite, Silicon Chem, 2008, 3, 6, 295-301, https://doi. org/10.1007/s11201-007-9031-1.

17.ASTM: E 2149-10, Standard test methods for determining the antimicrobial activity of immobilized antimicrobial agents under dynamic contacts condition.

18.Malcolm, K., Woolfson, D., Russell, J., Tallon, P., Mc Auley, L., Craig, D., Influence of silicone elastomer solubility and diffusivity on the in vitro release of drug from intravaginal rings, $J$ Control Release, 2003, 90, 2, 217-225, https:// doi.org/10.1016/S0168-3659(03)00178-0.

19.Nituica, M., Sonmez, M., Stelescu, M.D., Gurau, D., Curutiu, C., Ditu, L.M., Polymer nanocomposite based on silicone rubber reinforced with nanoparticles processed by vulcanization, Sci Bull B Chem Mater Sci, 2017, 79, 4, 63-72, ISSN:1454-2331, Accession Number: WOS:000424134600007.

20.Nituica (Vilsan), M., Sonmez, M., Georgescu, M., Stelescu, M.D., Alexandrescu, L., Gurau, D., Curutiu, C., Ditu, L.M., Antibacterial nanocompound based on silicone rubber. Part II - Biological Characterization, Leather and Footwear Journal, 2019, 19, 4, 227-232, https://doi.org/10.24264/Ifj.19.4.7.

21. Nituica (Vilsan), M., Sonmez, M., Georgescu, M., Stelescu, M.D., Alexandrescu, L., Gurau, D., Curutiu, C., Ditu, L.M., Antibacterial compound based on silicone rubber and $\mathrm{ZnO}$ and $\mathrm{TiO}_{2}$ nanoparticles for the food and pharmaceutic industries. Part I - Obtaining and Characterisation, Leather and Footwear Journal, 2020, 20, 2, 173-182, https://doi. org/10.24264/Ifj.20.2.8.

22. Nituica, M., Alexandrescu, L., Stelescu, M.D., Sonmez, M., Georgescu, M., Antibacterial polymer composite based on silicone elastomer and $\mathrm{ZnO}$ and $\mathrm{TiO}_{2}$, Patent no.132483, 2019.

(C) 2020 by the author(s). Published by INCDTPICPI, Bucharest, RO. This is an open access article distributed under the terms and conditions of the Creative Commons Attribution license (http:// creativecommons.org/licenses/by/4.0/). 